R. F. Hudson diskutiert eine Anwendung des Konzepts der weichen und harten Säuren und Basen auf die Geschwindigkeiten von Substitutionsreaktionen. Dabei kommt er zu dem Ergebnis, daß dieses Konzept am besten bei anorganischen Systemen anwendbar ist, soweit es sich nicht um Ionen handelt, die eine Möglichkeit der Bindungsisomerie bieten.

Schließlich bemühen sich R. J. P. WrLltams und J. D. HAtE in ihrem Beitrag um eine Klassifizierung von Donor- und Akzeptorionen bzw. -molekülen, wobei ihnen besonders thermodynamische Daten als experimentelle Grundlagen dienen. Ihre Betonung der Schwierigkeiten bei einer konsequenten Einteilung unter Berücksichtigung der Bezugszustände verdient besondere Anerkennung.

Über einheitliche, stilistische Ausführung, Aufbau und Darstellung dieses Bandes zu sprechen, erübrigt sich bei der offensichtlichen Heterogenität des Buches. Eine Herausgabe der folgenden Bände unter jeweils einem einheitlichen Untertitel wäre sehr zu begrüßen.

H. KELM

\title{
Erratum
}

\section{Crystal, Molecular and Electronic Structure of 1,1-diaryl-2-halogenoethylenes}

\section{Semiempirical Calculations on the Crystal, Molecular and Electronic Structure of 2-bromo-1,1-diphenylprop-1-ene}

\author{
Gian luigi Casalone, Carla Mariani, Aqgelo Mugroli \\ and Massimo Stmonetra
}

Theoret. chim. Acta (Berl.) 8, 228-235 (1967)

Received September 15, 1967

In Fig. 3, 4 and 5 the direction of the arrows must be reversed.

At page 232, fourth line from the bottom, read C2 instead of $\mathrm{C} 1$.

In Fig. 5 a read $\varphi_{1}=119^{\circ}$ instead of $\varphi_{1}=118^{\circ}$;

in Fig. $5 \mathrm{a}$ and $5 \mathrm{~b}$ the $\mathrm{C} 1 \widehat{\mathrm{C} 2} \mathrm{Br}$ angle is equal to $113^{\circ}$. 